\title{
PENGARUH DISIPLIN KERJA, MOTIVASI KERJA, ETOS KERJA DAN LINGKUNGAN KERJA TERHADAP PRODUKTIVITAS KERJA KARYAWAN BAGIAN PRODUKSI DI PT. INKO JAVA SEMARANG
}

\author{
Oleh : \\ Abdul Rachman Saleh \\ Alumni STIE AMA Salatiga \\ Hardi Utomo \\ Dosen STIE AMA Salatiga
}

\begin{abstract}
ABSTRAK
Tujuan penelitian ini adalah untuk menguji pengaruh disiplin kerja, motivasi kerja, etos kerja dan lingkungan kerja terhadap produktivitas kerja karyawan. Sampel dalam penelitian ini adalah karyawan bagian produksi di PT. Inko Java. Analisis data menggunakan analisis uji validitas, uji reliabilitas dan analisis regresi berganda. Pengujian hipotesis menggunakan uji $t$, uji $F$, dan koefisien determinasi. Hasil persamaan regresi dari penelitian yang dilakukan adalah $Y=3,495+0,151 X_{1}+$ $0,325 X_{2}+0,122 X_{3}-0,020 X_{4}$. Analisis setiap variabel menunjukan bahwa variabel disiplin kerja mempunyai t hitung 1,767 < t tabel yaitu 1,99, variabel motivasi kerja mempunyai t hitung 5,047 > t tabel yaitu 1,99, variabel etos kerja mempunyai thitung 1,375 < t tabel yaitu 1,99, dan variabel lingkungan kerja mempunyai t hitung -0,267 $<-t$ tabel yaitu -1,99. Hal ini menunjukan bahwa variabel disiplin kerja mempunyai hasil positif namun tidak berpengaruh signifikan terhadap produktivitas kerja, variabel motivasi kerja ada pengaruh signifikan terhadap produktivitas kerja, variabel etos kerja mempunyai hasil positif namun tidak berpengaruh signifikan terhadap produktivitas kerja, dan variabel lingkungan kerja mempunyai hasil negatif dan tidak berpengaruh signifikan terhadap produktivitas kerja. Sedangkan keempat variabel yaitu disiplin kerja, motivasi kerja, etos kerja dan lingkungan kerja secara bersama-sama mempunyai $F$ hitung 9,256 > F tabel yaitu 2,52. Hal ini menunjukan bahwa terdapat pengaruh signifikan disiplin kerja, motivasi kerja, etos kerja dan lingkungan kerja secara simultan terhadap produktivitas kerja karyawan PT. Inko Java. Kemampuan variabel independen disiplin kerja $\left(X_{1}\right)$, motivasi kerja $\left(X_{2}\right)$, etos kerja $\left(X_{3}\right)$, dan lingkungan kerja $\left(X_{4}\right)$ dalam menjelaskan variabel dependen produktivitas kerja $(Y)$ adalah Adjusted $R$ Square 33,7\% sedang sisanya sebesar $66,3 \%$ dijelaskan oleh variabel lainnya yang tidak diteliti. Dari analisis tersebut, maka saran yang diberikan adalah sebagai berikut: perusahaan harus lebih memperhatikan dan mengupayakan hal yang dapat meningkatkan disiplin kerja, motivasi kerja dan etos kerja karena dengan meningkatnya ketiga hal tersebut produktivitas kerja yang menjadi target perusahaan dapat tercapai, selain itu perusahaan juga perlu lebih memperhatikan perihal lingkungan kerja karyawan agar tercipta hasil yang seimbang antara apa yang telah perusahaan berikan dengan apa yang telah karyawan kontribusikan kepada perusahaan.
\end{abstract}

Kata Kunci : Disiplin Kerja, Motivasi Kerja, Etos Kerja, Lingkungan Kerja dan Produktivitas Kerja 


\section{PENDAHULUAN}

Manajemen memegang peranan penting dalam peningkatan efisiensi dan efektifitas dari sebuah perusahaan. Menurut Hasibuan (2012:9) Manajemen adalah ilmu dan seni mengatur proses pemanfaatan sumber daya manusia dan sumber-sumber daya lainnya secara efektif dan efisien untuk mencapai suatu tujuan tertentu.

Diantara banyak tujuan perusahaan adalah memperoleh laba dan menjadi yang terbaik dalam memenuhi kebutuhan konsumen, berdasarkan pada dua hal tersebut perusahaan dituntut untuk dapat terus berproduktif menghasilkan produk dengan kualitas dan mutu terbaik dan berkelanjutan. Oleh karena itu produktivitas kerja karyawan adalah sangat penting, karena dengan produktivitas yang baik perusahaan akan mampu menyediakan produk yang dibutuhkan oleh konsumen secara berkelanjutan dan sejalan dengan itu target laba perusahaan dapat tercapai.

Banyak faktor yang dapat mempengaruhi tinggi rendahnya produktivitas kerja karyawan, diataranya adalah disiplin kerja dari diri seorang karyawan, motivasi atau dorongan kerja, etos atau semangat kerja seorang karyawan dan didukung dengan lingkungan kerja tempat berlangsungnya kegiatan kerja setiap harinya. Seorang karyawan yang memiliki kedisiplinan, motivasi dan semangat kerja yang tinggi akan mampu melakukan pekerjaannya secara baik dan maksimal, dengan demikian target produktivitas perusahaan akan tercapai.

Simamora (2004:110) mengemukakan bahwa produktivitas kerja karyawan adalah kemampuan memperoleh manfaat sebesar-besarnya dari sarana dan prasarana yang tersedia dengan menghasilkan output dan input yang optimal.NSelanjutnya faktor yang juga mempengaruhi produktivitas kerja karyawan adalah Etos Kerja. Menurut Sinamo (2005:2) menyatakan bahwa etos kerja adalah seperangkat perilaku kerja positif yang berakar pada kesadaran yang kental, keyakinan yang fundamental, disertai komitmen yang total pada paradigma kerja integral. Hal diatas merupakan faktor produktivitas kerja karyawan yang bersumber dari dalam diri seorang karyawan, produktivitas kerja karyawan juga dipengaruhi hal yang berasal dari internal perusahaan, diantaranya yaitu lingkungan kerja. Lingkungan kerja memegang peranan penting dalam kegiatan perusahaan, karena lingkungan kerja adalah tempat sehari-hari karyawan 
melakukan aktivitas pekerjaannya. Dengan lingkungan kerja yang nyaman dan kondusif, maka diharapkan akan mampu memberikan kenyamanan dan akan mendorong para karyawan lebih giat bekerja dan secara otomatis produktivitas yang diharapkan perusahaan dapat tercapai. Menurut Sedarmayanti (2009:21) Lingkungan Kerja merupakan keseluruhan alat perkakas dan bahan yang dihadapi, lingkungan sekitarnya dimana seorang bekerja, metode kerjanya, serta pengaturan kerjanya baik sebagai perorangan maupun sebagai kelompok.

PT. Inko Java yang terletak di Jl. Raya PTP XVIII Ngobo, Karangjati, Bergas, Kabupaten Semarang, adalah perusahaan yang bergerak di bidang manufaktur yang memproduksi alat olahraga yaitu sarung tangan baseball dan softball. Dalam perkembangannya perusahaan ini telah memiliki tiga anak perusahaan yang masing-masing berada di Osaka Jepang, Busan Korea Selatan, dan Los Angeles California Amerika Serikat. Perusahaan ini dalam posisinya sebagai perusahaan Vendor penyedia barang sesuai dengan pesanan atau order dituntut untuk dapat menyediakan barang tepat waktu dan sesuai dengan pesanan. Oleh karena itu produktivitas kerja para karyawan sangatlah penting untuk mendukung pemenuhan permintaan barang agar tidak terjadi masalah. Dalam kegiatan produksinya, produktivitaslah yang menjadi masalah utama yang dihadapi oleh perusahaan. Hasil produksi setiap harinya mengalami gejolak naik turun tidak sesuai dengan target pencapaian yang telah ditetapkan oleh perusahaan.

Berdasarkan data perusahaan hasil barang jadi dapat dikatakan bahwa produktivitas hasil barang jadi setiap bulannya mengalami kenaikan dan penurunan. Hal ini terlepas dari karena jumlah order setiap bulannya yang berbeda, dalam kesehariannya untuk mencapai angka produktivitas yang telah ditetapkan oleh manajemen adalah sangat sulit dicapai melalui perhitungan jam kerja normal sehingga menuntut pihak manajemen melakukan keputusan menerapkan sistem kerja lembur demi pencapaian angka target produksi per harinya.

Menurut Manajer Produksi PT. Inko Java, standar produksi per hari kerja yang telah ditetapkan oleh manajemen adalah standar angka wajib yang harus dicapai oleh karyawan, yaitu sebesar 610 pes sarung tangan per hari, tetapi juga diharapkan para karyawan mampu berproduksi melebihi standar yang ditetapkan. 
Banyak hal yang mempengaruhi naik turunnya hasil produksi per hari, diantaranya kurangnya disiplin dan semangat kerja karyawan, kurang maksimalnya peranan para kepala bagian (section chief) produksi mengakibatkan para karyawan bekerja secara santai tanpa memperhatikan pencapaian target produksi setiap harinya serta yang tidak kalah berkontribusi dalam penurunan atau tidak tercapainya produktivitas adalah lingkungan kerja yang dirasa kurang nyaman oleh para karyawan.

Berdasarkan paparan diatas maka penelitian ini berusaha mengetahui hal-hal yang mempengaruhi produktivitas kerja karyawan di PT. Inko Java Semarang. Oleh karena itu, dibuat penelitian dengan judul Pengaruh Disiplin Kerja, Motivasi Kerja, Etos Kerja dan Lingkungan Kerja Terhadap Produktivitas Kerja Karyawan di PT. Inko Java Semarang.

\section{RUMUSAN MASALAH}

Berdasarkan uraian latar belakang diatas, maka rumusan masalah dalam penelitian ini adalah sebagai berikut :

1. Apakah Disiplin Kerja berpengaruh terhadap Produktivitas Kerja Karyawan pada PT. Inko Java?

2. Apakah Motivasi Kerja berpengaruh terhadap Produktivitas Kerja Karyawan pada PT. Inko Java?

3. Apakah Etos Kerja berpengaruh terhadap Produktivitas Kerja Karyawan pada PT. Inko Java?

4. Apakah Lingkungan Kerja berpengaruh terhadap Produktivitas Kerja Karyawan pada PT. Inko Java?

5. Apakah Disiplin Kerja, Motivasi Kerja, Etos Kerja dan Lingkungan Kerja berpengaruh secara Simultan terhadap Produktivitas Kerja Karyawan pada PT. Inko Java?

\section{TUJUAN PENELITIAN}

a. Untuk mengetahui pengaruh Disiplin Kerja terhadap Produktivitas Kerja Karyawan pada PT. Inko Java.

b. Untuk mengetahui pengaruh Motivasi Kerja terhadap Produktivitas Kerja Karyawan pada PT. Inko Java. 
c. Untuk mengetahui pengaruh Etos Kerja terhadap Produktivitas Kerja Karyawan pada PT. Inko Java.

d. Untuk mengetahui pengaruh Lingkungan Kerja terhadap Produktivitas Kerja Karyawan pada PT. Inko Java.

e. Untuk mengetahui pengaruh Disiplin Kerja, Motivasi Kerja, Etos Kerja dan Lingkungan Kerja secara Simultan terhadap Produktivitas Kerja Karyawan pada PT. Inko Java.

\section{LANDASAN TEORI}

\section{Disiplin Kerja}

Disiplin merupakan suatu proses yang dapat menumbuhkan perasaan seseorang untuk mempertahankan dan meningkatkan tujuan organisasi secara objektif, melalui kepatuhannya menjalankan peraturan organisasi. Kedisiplinan adalah hal utama yang wajib dijunjung oleh seorang individu atau karyawan untuk menunjukan kepada perusahaan bahwa dia mampu memegang tanggung jawab yang diberikan kepadanya dengan baik maupun hal lain yang diembankan oleh perusahaan kepadanya. Melalui disiplin kerja akan mampu meningkatakan produktivitas kerja.

Disiplin Kerja menurut Sastrohadiwiryo (2013:291) adalah suatu sikap menghormati, menghargai, patuh, dan taat terhadap peraturan-peraturan yang berlaku, baik yang tertulis maupun tidak tertulis serta sanggup menjalankannya dan tidak mengelak untuk menerima sanksi-sanksinya apabila ia melanggar tugas dan wewenang yang diberikan kepadanya. Adapun indikator yang dapat digunakan sebagai tolak ukur disiplin kerja seorang karyawan, yaitu : frekuensi kehadiran, tingkat kewaspadaan, ketaatan pada standar kerja, ketaatan pada peraturan kerja, etika kerja.

\section{Motivasi Kerja}

Istilah motivasi berasal dari bahasa latin "movere" yang sama dengan "to move" (bahasa Inggris) yang artinya mendorong atau menggerakkan. Motivasi merupakan proses psikologis yang timbul diakibatkan oleh faktorfaktor yang bersumber baik dari dalam maupun dari luar diri seseorang. Melalui motivasi kerja seseorang akan mampu melakukan tanggung jawab pekerjaannya secara maksimal dan dengan demikian target/tujuan perusahaan 
akan tercapai. Pemberian motivasi wajib dilakukan oleh seorang pemimpin kepada bawahan, dan untuk melakukannya seorang pemimpin harus mengetahui motif dan motivasi yang diinginkan oleh karyawan.

Menurut Sastrohadiwiryo (2013:119) Motivasi dapat diartikan sebagai keadaan kejiwaan dan sikap mental manusia yang memberikan energi, mendorong kegiatan (moves), dan mengarah atau menyalurkan perilaku ke arah mencapai kebutuhan yang memberikan kepuasan atau mengurangi ketidakseimbangan. Adapun Indikator yang dapat digunakan untuk mengukur Motivasi Kerja seorang karyawan adalah sebagai berikut : Kinerja (Achievement), Penghargaan (Recognition), Tantangan (Challenge), Tanggung Jawab (Responsibility), Pengembangan (Development), Keterlibatan (Involvement), dan Kesempatan (Opportunities).

\section{Etos Kerja}

Secara umum Etos Kerja merupakan semua kebiasaan baik meliputi disiplin, jujur, tanggung jawab, tekun, sabar yang berdasar pada etika yang harus dilakukan di tempat kerja. Tanpa memiliki etos kerja seperti yang telah disebutkan diatas, seorang karyawan akan merasa terbebani dengan seluruh tanggung jawab pekerjaan dan dampak buruknya tidak akan mampu meningkatkan produktivitas perusahaan sesuai dengan target yang diinginkan.

Performa dalam bekerja seseorang karyawan sangat ditentukan dan dipengaruhi oeh etos kerja yang dimilikinya. Menurut Sinamo (2005:2) menyatakan bahwa Etos Kerja adalah seperangkat perilaku kerja positif yang berakar pada kesadaran yang kental, keyakinan yang fundamental, disertai komitmen yang total pada paradigma kerja integral. Adapun indikatorindikator di dalam Etos Kerja menurut Sinamo (2005:151) yaitu : Penuh tanggung jawab, Semangat kerja yang tinggi, Berdisiplin, Tekun dan serius, Menjaga martabat dan kehormatan.

\section{Lingkungan Kerja}

Lingkungan Kerja adalah salah satu komponen dalam sebuah perusahaan yang harus menjadi perhatian oleh pihak manajemen. Dalam konteks perusahaan manufaktur, Lingkungan kerja memegang peranan penting dalam kegiatan perusahaan. Lingkungan Kerja adalah tempat dimana produk 
perusahaan dihasilkan. Menurut Sedarmayanti (2009:21) Lingkungan kerja adalah keseluruhan alat perkakas dan bahan yang dihadapi, lingkungan sekitarnya di mana seseorang bekerja, metode kerjanya, serta pengaturan kerjanya baik sebagai perseorangan maupun sebagai kelompok. Ada beberapa faktor yang terkait dengan pengaruh lingkungan kerja terhadap kemampuan seseorang karyawan menurut Sedarmayanti (2009:21), berikut diataranya : Penerangan, Suhu udara, Suara bising, warna dan tata letak/ruang gerak, Keamanan dan hubungan karyawan.

\section{Produktivitas Kerja}

Produktivitas adalah ukuran dari kualitas dan kuantitas dari pekerjaan yang telah dikerjakan, dengan mempertimbangkan biaya sumber daya yang digunakan untuk mengerjakan pekerjaan. Produktivitas diartikan sebagai tingkatan efisiensi dalam memproduksi barang-barang atau jasa-jasa: "Produktivitas mengutarakan cara pemanfaatan secara baik terhadap sumbersumber dalam memproduksi barang" ( Sinungan, 2014:12).

Menurut Simamora (2004:110) Produktivitas kerja karyawan adalah kemampuan memperoleh manfaat sebesar-besarnya dari sarana dan prasarana yang tersedia dengan menghasilkan Ouput dan Input yang optimal. Dalam penelitian ini peneliti mengukur produktivitas kerja karyawan dengan menggunakan indikator-indikator yang dikemukakan oleh Simamora (2004:112) yaitu : Kuantitas kerja, Kualitas Kerja, Ketepatan waktu penyelesaian pekerjaan dan sikap kooperatif.

\section{KERANGKA PEMIKIRAN}

Kerangka pikiran merupakan penjelasan secara teoritis pertautan antara variable yang diteliti, yang disusun dari berbagai teeori yang dideskripsikan Sugiono, 2004:49).

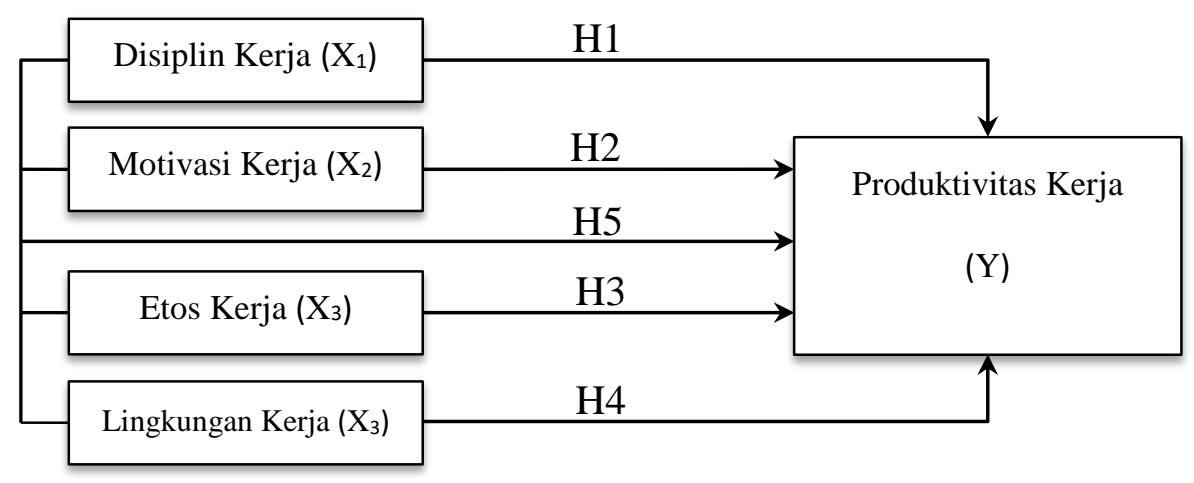




\section{METODE PENELITIAN}

\section{Populasi dan Sampel}

Populasi dalam penelitian ini yaitu seluruh karyawan bagian produksi di PT. Inko Java berjumlah 198 orang. Dan besarnya sampel yang digunakan dalam penelitian ini ditentukan dengan menggunakan rumus slovin yaitu diperoleh jumlah sampel sebanyak 66 orang. Dalam penelitian ini menggunakan teknik pengambilan sampel secara Non-probability purposive sampling. Menurut Sugiyono (2012:66) Non-probability purposive sampling adalah teknik pengambilan sampel yang tidak memberi peluang atau kesempatan sama bagi setiap unsur atau anggota populasi untuk dipilih menjadi sampel yaitu dengan beberapa pertimbangan tertentu yang bertujuan agar data yang diperoleh nantinya bisa lebih representatif. Dimana dalam penentuan sampel ini peneliti mempertimbangkan orang per orang yang dianggap memiliki capability atau mampu menelaah setiap pernyataan dalam kuesioner dengan baik.

\section{Definisi Operasional}

Menurut Sugiyono (2012:31) definisi operasional adalah penentuan konstruk atau sifat yang akan dipelajari sehingga menjadi variabel yang dapat diukur.

\section{1) Disiplin Kerja $\left(X_{1}\right)$}

Adapun indikator Disiplin Kerja menurut Sastrohadiwiryo (2013:291) yaitu :
a) Frekuensi Kehadiran
b) Tingkat Kewaspadaan
c) Ketaatan pada standar kerja
d) Ketaaatan pada peraturan kerja
e) Etika Kerja

2) Motivasi Kerja $\left(\mathbf{X}_{2}\right)$

Adapun indikator Motivasi Kerja menurut Sastrohadiwiryo (2013:268) yaitu :

a) Kinerja

b) Penghargaan 

c) Tantangan dan tanggung jawab
d) Pengembangan
e) Keterlibatan dan kesempatan

\section{3) Etos Kerja (X3)}

Adapun indikator Etos Kerja menurut Sinamo (2005:151) yaitu :
a) Penuh tanggung jawab
b) Semangat kerja yang tinggi
c) Berdisiplin
d) Tekun dan serius
e) Menjaga martabat dan kehormatan

\section{4) Lingkungan Kerja $\left(\mathrm{X}_{4}\right)$}

Adapun indikator Lingkungan Kerja menurut Sedarmayanti (2009:46) yaitu :
a) Penerangan
b) Suhu udara
c) Suara bising
d) Warna dan ruang gerak
e) Keamanan dan hubungan karyawan

\section{5) Produktivitas Kerja (Y)}

Adapun indikator Produktivitas Kerja menurut Simamora (2004:112) yaitu :
a) Kuantitas kerja
b) Kualitas kerja
c) Ketepatan waktu penyelesaian suatu pekerjaan
d) Sikap Kooperatif, meliputi sikap terhadap organisasi, pimpinan, karyawan lain dan kerja sama.

\section{ANALISIS DATA}

\section{Uji Validitas}

Uji validitas dilakukan untuk mengetahui apakah instrument (kuesioner) dapat mengukur variabel yang diteliti secara tepat dalam suatu penelitian.. Apabila nilai $r$ hitung lebih besar dari nilai $r$ tabel dan nilai positif maka butir atau 
pernyataan atau indikator tersebut dinyatakan Valid. Adapun hasil uji Validitas adalah sebagai berikut :

Tabel 1

Hasil Uji Validitas Butir Kuesioner

\begin{tabular}{|c|c|c|c|c|c|}
\hline $\begin{array}{c}\text { Variabel } \\
\text { Penelitian }\end{array}$ & $\begin{array}{c}\text { Butir } \\
\text { Pernyataan } \\
\text { Dalam } \\
\text { Kuesioner }\end{array}$ & $\begin{array}{c}\text { Koefisien } \\
\text { Korelasi } \\
\text { (r hitung) }\end{array}$ & $\begin{array}{l}\text { Nilai Kritis } \\
\text { (r tabel) }\end{array}$ & $\begin{array}{l}\text { Taraf Sig. } \\
(\mathrm{a}=0.05)\end{array}$ & Keterangan \\
\hline \multirow{5}{*}{$\begin{array}{c}\text { Disiplin Kerja } \\
\left(\mathrm{X}_{1}\right)\end{array}$} & $\mathrm{X} 1.1$ & 0,815 & 0,242 & 0,05 & Valid \\
\hline & $\mathrm{X} 1.2$ & 0,826 & 0,242 & 0,05 & Valid \\
\hline & $X 1.3$ & 0,864 & 0,242 & 0,05 & Valid \\
\hline & $\mathrm{X} 1.4$ & 0,811 & 0,242 & 0,05 & Valid \\
\hline & $\mathrm{X} 1.5$ & 0,831 & 0,242 & 0,05 & Valid \\
\hline \multirow{5}{*}{$\begin{array}{l}\text { Motivasi Kerja } \\
\qquad\left(\mathrm{X}_{2}\right)\end{array}$} & $\mathrm{X} 2.1$ & 0,795 & 0,242 & 0,05 & Valid \\
\hline & $\mathrm{X} 2.2$ & 0,753 & 0,242 & 0,05 & Valid \\
\hline & $\mathrm{X} 2.3$ & 0,646 & 0,242 & 0,05 & Valid \\
\hline & X2.4 & 0,626 & 0,242 & 0,05 & Valid \\
\hline & X2.5 & 0,825 & 0,242 & 0,05 & Valid \\
\hline \multirow{5}{*}{ Etos Kerja $\left(\mathrm{X}_{3}\right)$} & X3.1 & 0,840 & 0,242 & 0,05 & Valid \\
\hline & $\mathrm{X} 3.2$ & 0,752 & 0,242 & 0,05 & Valid \\
\hline & X3.3 & 0,863 & 0,242 & 0,05 & Valid \\
\hline & X3.4 & 0,841 & 0,242 & 0,05 & Valid \\
\hline & X3.5 & 0,802 & 0,242 & 0,05 & Valid \\
\hline \multirow{5}{*}{$\begin{array}{l}\text { Lingkungan } \\
\text { Kerja }\left(\mathrm{X}_{4}\right)\end{array}$} & $\mathrm{X} 4.1$ & 0,368 & 0,242 & 0,05 & Valid \\
\hline & $\mathrm{X} 4.2$ & 0,596 & 0,242 & 0,05 & Valid \\
\hline & $\mathrm{X} 4.3$ & 0,715 & 0,242 & 0,05 & Valid \\
\hline & $\mathrm{X} 4.4$ & 0,771 & 0,242 & 0,05 & Valid \\
\hline & $X 4.5$ & 0,778 & 0,242 & 0,05 & Valid \\
\hline \multirow{4}{*}{$\begin{array}{l}\text { Produktivitas } \\
\text { Kerja (Y) }\end{array}$} & Y1.1 & 0,808 & 0,242 & 0,05 & Valid \\
\hline & Y1.2 & 0,889 & 0,242 & 0,05 & Valid \\
\hline & Y1.3 & 0,895 & 0,242 & 0,05 & Valid \\
\hline & Y1.4 & 0,752 & 0,242 & 0,05 & Valid \\
\hline
\end{tabular}

Sumber : Data Primer, diolah Januari 2018

Dari Tabel 1 diatas dapat dilihat bahwa dari kelima variabel yang digunakan dalam penelitian ini terdiri dari 24 butir pernyataan mempunyai nilai koefisien korelasi ( $\mathrm{r}$ hitung) lebih besar dari nilai kritis ( $\mathrm{r}$ tabel), yang artinya bahwa setiap butir-butir pernyataan pada tiap variable tersebut adalah Valid. Adapun cara memperoleh nilai $r$ tabel adalah $\mathrm{df}=\mathrm{n}$ 2, maka 66-2=64, lalu angka 64 tersebut dicari nilainya dalam tabel r, dan didapatkan nilai $r_{\text {tabel }}$ sebesar 0,242.

\section{Uji Reliabilitas}

Uji Reliabilitas ini dimaksudkan untuk mengetahui apakah instrument yang digunakan dalam penelitian merupakan suatu instrument yang 
handal, konsistensi dan stabil, atau dengan kata lain apabila digunakan beberapa kali untuk mengukur objek yang sama akan menghasilkan data yang sama. Tingkat reliabilitas suatu variable penelitian dapat dilihat dari hasil statistic Cronbach's Alpha $(\alpha)$. Suatu variable dikatakan reliabel apabila memberikan nilai Cronbach's Alpha $>0,60$.

Adapun hasil uji reliabilitas yang dilakukan terhadap instrument penelitian ini dapat dilihat pada tabel dibawah ini.

Tabel 2

Hasil Uji Reliabilitas Instrumen

\begin{tabular}{|c|c|c|c|}
\hline Variabel Penelitian & Cronbach's Alpha & Alpha Pembanding & Keterangan \\
\hline Disiplin Kerja (X1) & 0.886 & 0.60 & Reliabel \\
\hline Motivasi Kerja (X2) & 0.775 & 0.60 & Reliabel \\
\hline Etos Kerja (X3) & 0.879 & 0.60 & Reliabel \\
\hline Lingkungan Kerja (X4) & 0.661 & 0.60 & Reliabel \\
\hline Produktivitas Kerja (Y) & 0.853 & 0.60 & Reliabel \\
\hline
\end{tabular}

Sumber : Data primer, diolah Januari 2018

Dari Tabel 2 diatas dapat dilihat bahwa seluruh instrument (variable penelitian) yang digunakan dalam penelitian ini dinyatakan Reliabel, karena nilai Cronbach's Alpha dari setiap variabel lebih besar dari Alpha pembanding. Oleh karena itu, dapat disimpulkan bahwa seluruh variabel pada penelitian ini dapat dipercaya serta memiliki konsistensi pengukuran yang baik sehingga dapat terus digunakan untuk penelitian selanjutnya.

\section{Analisis Regresi Linear Berganda}

Analisi regresi linear berganda digunakan untuk mengetahui seberapa besar pengaruh variabel bebas terhadap variabel terikat, yaitu : Disiplin Kerja $\left(\mathrm{X}_{1}\right)$, Motivasi Kerja $\left(\mathrm{X}_{2}\right)$, Etos Kerja $\left(\mathrm{X}_{3}\right)$, dan Lingkungan Kerja $\left(\mathrm{X}_{4}\right)$ terhadap Produktivitas Kerja (Y). Adapun pengolahan dari Analisis Regresi Linear Berganda tersebut, diperoleh data sebagai berikut: 
Tabel 3

Hasil Analisis Regresi Linear Berganda

\begin{tabular}{|c|c|c|c|c|c|c|}
\hline \multicolumn{7}{|c|}{ Coefficients } \\
\hline \multirow{2}{*}{\multicolumn{2}{|c|}{ Model }} & \multicolumn{2}{|c|}{$\begin{array}{c}\text { Unstandardized } \\
\text { Coefficients }\end{array}$} & \multirow{2}{*}{$\begin{array}{c}\text { Standardize } \\
\text { d } \\
\text { Coefficients } \\
\text { Beta } \\
\end{array}$} & \multirow[b]{2}{*}{$\mathrm{t}$} & \multirow[b]{2}{*}{ Sig. } \\
\hline & & $\mathrm{B}$ & Std. Error & & & \\
\hline \multirow[t]{5}{*}{1} & (Constant) & 3.495 & 2.109 & & 1.657 & .103 \\
\hline & Disiplin Kerja & .151 & .085 & .226 & 1.767 & .082 \\
\hline & Motivasi Kerja & .325 & .064 & .533 & 5.047 & .000 \\
\hline & Etos Kerja & .122 & .089 & .173 & 1.375 & .174 \\
\hline & Lingkungan Kerja & -.020 & .074 & -.029 & -.267 & .790 \\
\hline
\end{tabular}

a. Dependent Variable: Produktivitas Kerja

Sumber : Data Primer, diolah Januari 2018

Berdasarkan tabel 3 diatas, maka dapat ditulis dalam bentuk persamaan regresi linear berganda sebagai berikut :

$$
Y=3,495+0,151 X_{1}+0,325 X_{2}+0,122 X_{3}-0,020 X_{4}
$$

Dari persamaan regresi diatas, maka dapat di interpretasikan beberapa hal yaitu :

\section{a. Nilai Konstanta $(\alpha)$}

Konstanta $(\alpha)$ sebesar 3,495 dan berarah positif, artinya apabila variable Disiplin Kerja $\left(\mathrm{X}_{1}\right)$, Motivasi Kerja $\left(\mathrm{X}_{2}\right)$, Etos Kerja $\left(\mathrm{X}_{3}\right)$ dan Lingkungan Kerja $\left(\mathrm{X}_{4}\right)$ diabaikan atau sama dengan 0, maka angka tersebut menunjukan besarnya nilai Produktivitas kerja karyawan (Y) sebesar 3,495.

\section{b. Nilai Koefisien Regresi Variabel Disiplin Kerja (b1)}

Koefisien regresi variabel Disiplin Kerja $\left(\mathrm{X}_{1}\right)$ sebesar 0,151; artinya apabila Disiplin Kerja mengalami kenaikan sebesar 1 satuan, maka Produktivitas Kerja Karyawan (Y) akan mengalami peningkatan sebesar 0,151 satuan dengan asumsi variabel lainnya dianggap tetap atau ceteris paribus. Koefisien bernilai positif antara Disiplin Kerja dengan Produktivitas kerja karyawan, maka semakin tinggi tingkat disiplin kerja karyawan maka produktivitas yang dihasilkan akan semakin tinggi pula. 


\section{c. Nilai Koefisien Regresi Variabel Motivasi Kerja (b2)}

Koefisien regresi variabel Motivasi Kerja $\left(\mathrm{X}_{2}\right)$ sebesar 0,325; artinya apabila Motivasi Kerja mengalami kenaikan sebesar 1 satuan, maka Produktivitas Kerja Karyawan (Y) akan mengalami peningkatan sebesar 0,325 satuan dengan asumsi variabel lainnya dianggap tetap atau ceteris paribus. Koefisien bernilai positif antara Motivasi Kerja dengan Produktivitas kerja karyawan, maka semakin tinggi motivasi kerja karyawan dalam bekerja maka produktivitas kerja yang dihasilkan oleh karyawan akan semakin tinggi pula.

\section{d. Nilai Koefisien Regresi Variabel Etos Kerja (b3)}

Koefisien regresi variabel Etos Kerja $\left(\mathrm{X}_{3}\right)$ sebesar 0,122; artinya apabila Etos Kerja mengalami kenaikan sebesar 1 satuan, maka Produktivitas Kerja Karyawan (Y) akan mengalami peningkatan sebesar 0,122 satuan dengan asumsi variabel lainnya dianggap tetap atau ceteris paribus. Koefisien bernilai positif antara Etos Kerja dengan Produktivitas kerja karyawan, maka semakin tinggi Etos kerja karyawan maka produktivitas yang dihasilkan akan semakin tinggi pula.

\section{e. Nilai Koefisien Regresi Variabel Lingkungan Kerja (b4)}

Koefisien regresi variabel Lingkungan Kerja $\left(\mathrm{X}_{4}\right)$ sebesar $(-0,020)$; artinya apabila Lingkungan Kerja mengalami kenaikan sebesar 1 satuan, maka Produktivitas Kerja Karyawan (Y) akan mengalami penurunan sebesar 0,020 satuan dengan asumsi variabel lainnya dianggap tetap atau ceteris paribus. Koefisien bernilai negatif antara Lingkungan Kerja dengan Produktivitas kerja karyawan, maka semakin tinggi Lingkungan kerja maka produktivitas yang dihasilkan akan semakin turun.

\section{Pengujian Hipotesis}

Pengujian hipotesis dilakukan guna mengetahui apakah sampel yang diambil dapat mewakili atau berlaku untuk populasi penelitian, sehingga perlu dilakukan uji signifikasi. 


\section{a. Uji t}

Uji t dimaksudkan untuk mengetahui tingkat signifikansi pengaruh masing-masing variabel bebas terhadap variabel terikat dengan asumsi variabel bebas yang lain tidak berubah. Dengan menggunakan program SPSS 18, dilakukan pengujian signifikasi parameter individu, pengujian dilakukan dengan menggunakan significance level $(\alpha=5 \%)$. Berikut adalah hasil output pengujian dengan program SPSS 18 :

\section{Tabel 4}

Uji t

\begin{tabular}{|c|c|c|c|c|c|c|}
\hline \multicolumn{7}{|c|}{ Coefficients $^{a}$} \\
\hline \multicolumn{2}{|c|}{ Model } & \multicolumn{2}{|c|}{$\begin{array}{c}\text { Unstandardized } \\
\text { Coefficients }\end{array}$} & \multirow{2}{*}{$\begin{array}{c}\text { Standardize } \\
\text { d } \\
\text { Coefficients } \\
\text { Beta } \\
\end{array}$} & \multirow[b]{2}{*}{$\mathrm{t}$} & \multirow[b]{2}{*}{ Sig. } \\
\hline & & $\mathrm{B}$ & Std. Error & & & \\
\hline \multirow[t]{5}{*}{1} & (Constant) & 3.495 & 2.109 & & 1.657 & .103 \\
\hline & Disiplin Kerja & .151 & .085 & .226 & 1.767 & .082 \\
\hline & Motivasi Kerja & .325 & .064 & .533 & 5.047 & .000 \\
\hline & Etos Kerja & .122 & .089 & .173 & 1.375 & .174 \\
\hline & Lingkungan Kerja & -.020 & .074 & -.029 & -.267 & .790 \\
\hline
\end{tabular}

a. Dependent Variable: Produktivitas Kerja

Sumber : Data primer, diolah Januari 2018

\section{1) Pengujian Hipotesis I penelitian : Ada pengaruh signifikan} Disiplin Kerja terhadap Produktivitas Kerja Karyawan pada

\section{PT. Inko Java.}

Berdasarkan pengujian diperoleh hasil ada pengaruh positif namun tidak signifikan variabel disiplin kerja dimana $\mathrm{t}$ hitung bernilai positif sebesar 1,767 terletak didalam daerah penerimaan Ho dan nilainya kurang dari nilai $\mathrm{t}$ tabel 1,99, maka dapat disimpulkan pernyataan hipotesis I penelitian "Ada pengaruh signifikan Disiplin Kerja terhadap Produktivitas Kerja Karyawan pada PT. Inko Java" ditolak. Artinya disiplin kerja berdasarkan indikator yang ada tidak berpengaruh signifikan terhadap produktivitas kerja karyawan. Berdasarkan data dari jawaban responden terhadap indikator disiplin kerja yang meliputi frekuensi kehadiran, tingkat kewaspadaan, ketaatan pada standar kerja, 
ketaatan pada peraturan kerja dan etika kerja, tidak signifikannya pengaruh disiplin kerja terhadap produktivitas kerja disebabkan karena kurangnya ketaatan karyawan pada peraturan kerja dan kurangnya sikap saling menjaga kesopanan antar sesama karyawan.

\section{2) Pengujian Hipotesis II penelitian : Ada pengaruh signifikan} Motivasi Kerja terhadap Produktivitas Kerja Karyawan pada PT. Inko Java.

Berdasarkan pengujian diperoleh hasil ada pengaruh positif secara parsial variabel motivasi kerja dimana t hitung bernilai positif sebesar 5,047 terletak didalam daerah penerimaan Ha dan nilainya lebih besar dari nilai t tabel, maka dapat disimpulkan pernyataan hipotesis II penelitian "Ada pengaruh signifikan Motivasi Kerja terhadap Produktivitas Kerja Karyawan pada PT. Inko Java" diterima. Artinya jika berdasarkan indikator motivasi yang terdiri dari kinerja, penghargaan yang diterima, rasa tertantang dan tanggung jawab dalam bekerja dimiliki oleh karyawan, sikap ingin berkembang, rasa ingin terlibat dan memanfaatkan kesempatan dapat memotivasi karyawan dalam bekerja maka akan meningkatkan produktivitas kerja karyawan.

\section{3) Pengujian Hipotesis III penelitian : Ada pengaruh signifikan} Etos Kerja terhadap Produktivitas Kerja Karyawan pada PT. Inko Java.

Berdasarkan pengujian diperoleh hasil ada pengaruh positif namun tidak signifikan variabel etos kerja dimana thitung bernilai positif sebesar 1,375 terletak didalam daerah penerimaan Ho dan nilainya kurang dari nilai $\mathrm{t}$ tabel, maka dapat disimpulkan pernyataan hipotesis III penelitian "Ada pengaruh signifikan Etos Kerja terhadap Produktivitas Kerja Karyawan pada PT. Inko Java” ditolak. Artinya etos kerja berdasarkan indikator yang ada tidak berpengaruh signifikan terhadap produktivitas kerja karyawan. Berdasarkan data dari jawaban responden terhadap indikator etos 
kerja yang meliputi penuh tanggung jawab, semangat kerja yang tinggi, berdisiplin, tekun dan serius, serta menjaga martabat dan kehormatan, tidak signifikannya pengaruh etos kerja terhadap produktivitas kerja disebabkan karena kurangnya semangat kerja pada diri karyawan dalam bekerja, kurangnya ketekunan dan tingkat keseriusan para karyawan dalam bekerja.

4) Pengujian Hipotesis IV penelitian : Ada pengaruh signifikan Lingkungan Kerja terhadap Produktivitas Kerja Karyawan pada PT. Inko Java.

Berdasarkan pengujian diperoleh hasil ada pengaruh negatif dan tidak signifikan variabel lingkungan kerja dimana -t hitung bernilai negatif sebesar $(-0,267)$ terletak didalam daerah penerimaan Ho dan nilainya kurang dari nilai -t tabel, maka dapat disimpulkan pernyataan hipotesis IV penelitian "Ada pengaruh signifikan Lingkungan Kerja terhadap Produktivitas Kerja Karyawan pada PT. Inko Java" ditolak. Artinya Lingkungan kerja berdasarkan indikator yang ada tidak berpengaruh signifikan terhadap produktivitas kerja karyawan. Berdasarkan data dari jawaban responden dan didukung dari hasil wawancara kepada para karyawan terhadap indikator lingkungan kerja yang meliputi penerangan, suhu udara, suara bising, warna dan tata letak serta keamanan dan hubungan karyawan, tidak signifikannya pengaruh lingkungan kerja terhadap produktivitas kerja karyawan yaitu karena menurut para karyawan dengan adanya penerangan yang terlalu terang akan membuat pandangan mata menjadi silau, suhu udara yang terlalu sejuk akan membuat para karyawan mengantuk, selain itu para karyawan sudah terbiasa bekerja pada lingkungan yang bising dan berisik. Sedangkan warna, tata letak dan keamanan tidak mempengaruhi karyawan dalam bekerja. Selain itu adanya anggapan para karyawan bahwa dengan lingkungan kerja yang baik dan nyaman, karyawan pasti akan dituntut untuk mencapai 
target produktivitas yang lebih tinggi sehingga mereka harus bekerja lebih keras demi pencapaian target produktivitas tersebut.

\section{Uji F}

Uji F dimaksudkan untuk menguji pengaruh variabel bebas yang meliputi Disiplin Kerja $\left(\mathrm{X}_{1}\right)$, Motivasi Kerja $\left(\mathrm{X}_{2}\right)$, Etos Kerja $\left(\mathrm{X}_{3}\right)$ dan Lingkungan Kerja $\left(\mathrm{X}_{4}\right)$ secara bersama-sama (simultan) terhadap variabel terikat yaitu Produktivitas Kerja Karyawan (Y) digunakan uji F apakah pengaruh tersebut bernilai positif atau negatif. Dengan menggunakan program SPSS 18, dilakukan pengujian signifikansi parameter secara bersama-sama, pengujian dilakukan dengan menggunakan significance level $(\alpha=5 \%)$ dengan kriteria jika diperoleh nilai $\mathrm{F}$ hitung < $\mathrm{F}$ tabel maka Ho diterima, dan apabila diperoleh nilai $\mathrm{F}$ hitung > F tabel maka Ho ditolak.

\section{Tabel 5}

Uji F

ANOVA

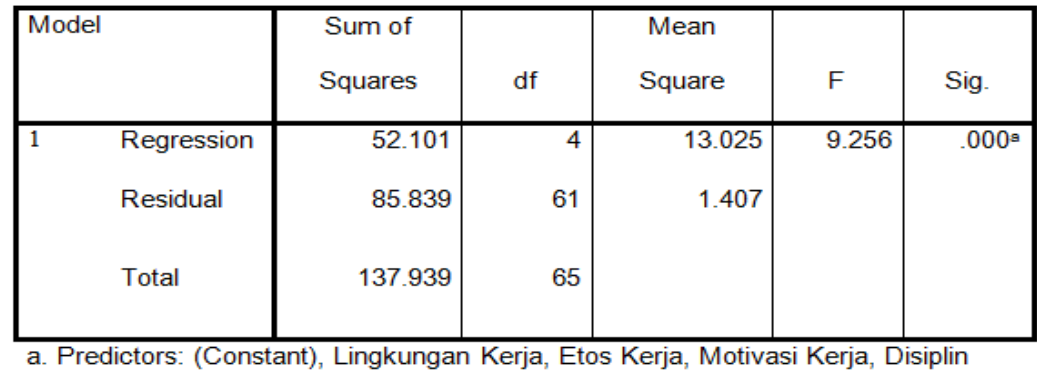

Kerja

b. Dependent Variable: Produktivitas Kerja

Sumber : Data primer, diolah Januari 2018

1) Pengujian Hipotesis $\mathrm{V}$ penelitian : Ada pengaruh signifikan Disiplin Kerja, Motivasi Kerja, Etos Kerja dan Lingkungan Kerja secara simultan terhadap Produktivitas Kerja Karyawan pada PT. Inko Java.

Berdasarkan pengujian diperoleh hasil ada pengaruh secara simultan variabel disiplin kerja $\left(\mathrm{X}_{1}\right)$, motivasi kerja $\left(\mathrm{X}_{2}\right)$, etos kerja $\left(\mathrm{X}_{3}\right)$, dan lingkungan kerja $\left(\mathrm{X}_{4}\right)$ dimana $\mathrm{F}$ hitung sebesar 9,256 terletak didalam daerah penolakan Ho dan nilainya lebih besar dari 
F tabel, maka dapat disimpulkan pernyataan hipotesis $\mathrm{V}$ penelitian

"Ada pengaruh signifikan Disiplin Kerja, Motivasi Kerja, Etos Kerja dan Lingkungan Kerja secara simultan terhadap Produktivitas Kerja Karyawan pada PT. Inko Java” diterima. Artinya jika disiplin kerja, motivasi kerja, etos kerja, dan lingkungan kerja bersama-sama ditingkatkan, maka produktivitas kerja karyawan juga akan meningkat.

\section{Koefisien Determinasi (KD)}

Koefisien Determinasi digunakan untuk mengetahui seberapa besar pengaruh variabel bebas terhadap variabel terikat yang ditunjukan dengan presentasi. Nilai koefisien determinasi adalah antara 0 dan 1 . Nilai koefisien determinasi kecil, berarti kemampuan variabel-variabel independen dalam menjelaskan variasi variabel dependen sangat terbatas. Nilai koefisien determinasi mendekati 1, berarti kemampuan variabelvariabel independen memberikan hampir semua informasi yang dibutuhkan untuk memprediksi variasi-variabel dependen (Ghozali, 2005:83). Dari hasil pengujian diperoleh nilai koefisien determinasi (Adjusted $\mathrm{R}^{2}$ ) $=0,337$. Hal ini menunjukan bahwa sebesar 33,7\% Produktivitas kerja karyawan (Y) dapat dijelaskan oleh variabel disiplin kerja $\left(\mathrm{X}_{1}\right)$, motivasi kerja $\left(\mathrm{X}_{2}\right)$, etos kerja $\left(\mathrm{X}_{3}\right)$, dan lingkungan kerja $\left(\mathrm{X}_{4}\right)$, sedangkan sisanya $(100 \%-33,7 \%=66,3 \%)$ dijelaskan oleh faktor-faktor lain yang tidak diteliti seperti kompensasi, gaya kepemimpinan, dan dari faktor operasional seperti kualitas bahan baku, proses produksi dan lainnya.

\section{SIMPULAN}

Berdasarkan hasil analisis data dan pembahasan, maka dapat ditarik simpulan sebagai berikut :

1. Dari hasil analisis regresi linear berganda diperoleh persamaan :

$$
Y=3,495+0,151 X_{1}+0,325 X_{2}+0,122 X_{3}-0,020 X_{4}
$$

Dari persamaan diatas, variabel Motivasi Kerja $\left(\mathrm{X}_{2}\right)$ memberikan kontribusi paling tinggi terhadap peningkatan Produktivitas Kerja karyawan (Y) di PT. Inko Java sebesar 0,325 satuan, variabel Disiplin 
Kerja $\left(\mathrm{X}_{1}\right)$ memberikan kontribusi sebesar 0,151 satuan, variabel Etos Kerja $\left(\mathrm{X}_{3}\right)$ memberikan kontribusi sebesar 0,122 satuan dan variabel Lingkungan Kerja $\left(\mathrm{X}_{4}\right)$ memberikan kontribusi negatif pada peningkatan Produktivitas Kerja karyawan (Y) sebesar (-0,020), serta konstanta variabel Produktivitas Kerja karyawan (Y) diperoleh hasil sebesar 3,495 dengan mengabaikan ke-empat variabel independen diatas.

2. Terdapat pengaruh positif namun tidak signifikan Disiplin Kerja $\left(\mathrm{X}_{1}\right)$ terhadap Produktivitas Kerja karyawan (Y) di PT. Inko Java, hal ini ditunjukan dengan diperolehnya hasil koefisien regresi sebesar 0,151 dan nilai $\mathrm{t}$ hitung sebesar 1,767 < nilai $\mathrm{t}$ tabel sebesar 1,99 pada taraf signifikansi $5 \%$.

3. Terdapat pengaruh positif dan signifikan Motivasi Kerja $\left(\mathrm{X}_{2}\right)$ terhadap Produktivitas Kerja karyawan (Y) di PT. Inko Java, hal ini ditunjukan dengan diperolehnya hasil koefisien regresi sebesar 0,325 dan nilai $\mathrm{t}$ hitung sebesar 5,047 > nilai t tabel sebesar 1,99 pada taraf signifikansi $5 \%$.

4. Terdapat pengaruh positif namun tidak signifikan Etos Kerja $\left(\mathrm{X}_{3}\right)$ terhadap Produktivitas Kerja karyawan (Y) di PT. Inko Java, hal ini ditunjukan dengan diperolehnya hasil koefisien regresi sebesar 0,112 dan nilai $\mathrm{t}$ hitung sebesar 1,375 < nilai $\mathrm{t}$ tabel sebesar 1,99 pada taraf signifikansi $5 \%$.

5. Tidak terdapat pengaruh positif dan tidak signifikan Lingkungan Kerja $\left(\mathrm{X}_{4}\right)$ terhadap Produktivitas Kerja karyawan (Y) di PT. Inko Java, hal ini ditunjukan dengan diperolehnya hasil koefisien regresi bernilai negatif sebesar $(-0,020)$ dan nilai -t hitung sebesar $(-0,267)<$ nilai $-t$ tabel sebesar $(-1,99)$ pada taraf signifikansi $5 \%$.

6. Terdapat pengaruh signifikan Disiplin Kerja $\left(\mathrm{X}_{1}\right)$, Motivasi Kerja $\left(\mathrm{X}_{2}\right)$, Etos Kerja $\left(\mathrm{X}_{3}\right)$, dan Lingkungan Kerja $\left(\mathrm{X}_{4}\right)$ secara bersama sama atau simultan terhadap Produktivitas Kerja karyawan (Y) di PT. Inko Java, hal ini ditunjukan dengan diperolehnya nilai $\mathrm{F}$ hitung sebesar 9,256 > nilai $\mathrm{F}$ tabel sebesar 2,52. 
7. Dari hasil pengujian Koefisien Determinasi $\left(\mathrm{R}^{2}\right)$ diperoleh hasil bahwa variabel independen yaitu Disiplin Kerja $\left(\mathrm{X}_{1}\right)$, Motivasi Kerja $\left(\mathrm{X}_{2}\right)$, Etos Kerja $\left(\mathrm{X}_{3}\right)$ dan Lingkungan Kerja $\left(\mathrm{X}_{4}\right)$ dalam menjelaskan variabel Dependen yaitu Produktivitas Kerja karyawan (Y) adalah sebesar 33,7\% dan sisanya 66,3\% dijelaskan oleh variabel lain yang tidak diteliti seperti kompensasi, gaya kepemimpinan, dan dari faktor operasional seperti kualitas bahan baku, proses produksi dan lainnya

\section{SARAN}

Dari simpulan yang telah disampaikan diatas maka sebagai sumbangan pemikiran peneliti memberikan saran sebagai berikut :

a. Disiplin Kerja $\left(\mathrm{X}_{1}\right)$ memiliki pengaruh terhadap produktivitas kerja karyawan sebesar 0,151. Untuk meningkatkan produktivitas kerja karyawan yang dapat dilakukan oleh pihak manajemen adalah dengan membuat peraturan dan standar kerja yang lebih jelas dan dapat dimengerti oleh setiap karyawan.

b. Motivasi kerja $\left(\mathrm{X}_{2}\right)$ memiliki pengaruh terhadap produktivitas kerja karyawan sebesar 0,325 . Untuk meningkatkan produktivitas kerja karyawan yang dapat dilakukan adalah dengan memberikan tambahan bonus/insentif bagi karyawan atau tim yang memiliki kinerja baik dan mampu menghasilkan produk sesuai dengan target yang ditetapkan, serta memberikan peluang terhadap pengembangan karir karyawan yaitu dengan promosi kenaikan jabatan.

c. Etos kerja $\left(\mathrm{X}_{3}\right)$ memiliki pengaruh terhadap produktivitas kerja karyawan sebesar 0,122 . Untuk meningkatkan produktivitas kerja karyawan yang dapat dilakukan adalah dengan menumbuhkan dan meningkatkan sikap etos kerja yang baik pada diri setiap karyawan. Salah satu caranya yaitu dengan pemberian motivasi baik internal maupun eksternal, misalnya dengan diadakannya acara gathering untuk mempertemukan karyawan antar departemen.

d. Lingkungan kerja $\left(\mathrm{X}_{4}\right)$ memiliki pengaruh terhadap produktivitas kerja karyawan sebesar (-0,020). Dari hasil penelitian ini lingkungan kerja bernilai negatif atau tidak berpengaruh terhadap peningkatan 
produktivitas kerja karyawan, meskipun demikian pihak manajemen tetap perlu menciptakan lingkungan kerja yang kondusif, nyaman dan disesuaikan dengan kebutuhan para karyawan disetiap bagiannya.

e. Pada penelitian selanjutnya dapat mengambil variabel lain yang dapat meningkatkan produktivitas kerja karyawan, antara lain kompensasi, gaya kepemimpinan, serta variabel-variabel yang berkaitan dengan manajemen operasional produksi seperti kualitas bahan baku, proses produksi dan lainnya.

\section{DAFTAR PUSTAKA}

Anoraga, Panji. 2001. Psikologi Kerja. Jakarta: Rineka Cipta.

Arikunto, S. 2006. Prosedur Penelitian Suatu Pendekatan Praktik. Jakarta: Rineka cipta.

Buana, Akbar Denia Nur. 2013. Pengaruh Disiplin Kerja terhadap Produktivitas Kerja Karyawan di Pabrik Pengolahan Karet PT. Perkebunan Nusantara (PTPN) VIII Wilayah Cikumpay-Purwakarta. Skripsi, Fakultas Bisnis dan Manajemen Universitas Widyatama, Bandung.

Faderika, Anggi Budi. 2016. Pengaruh Etos Kerja dan Kepuasan Kerja Terhadap Produktivitas Kerja Karyawan di Pertenunan Desa Boro Kalibawang Kabupaten Kulon Progo. Skripsi, Fakultas Keguruan dan Ilmu Pendidikan Universitas Sanata Dharma, Yogyakarta.

Ghozali, Imam. 2005. Aplikasi Analisis Multivariate Dengan Program SPSS. Semarang : Badan Penerbit Universitas Diponegoro.

Handoko, T. Hani. 2008. Manajemen Personalia dan Sumber Daya manusia, edisi kedua. Yogyakarta : BPFE.

Hasan, Iqbal. 2004. Analisis Data Penelitian dengan Statistik. Jakarta: PT Bumi Aksara.

Hasibuan, Malayu S.P. 2003. Manajemen Sumber Daya Manusia. Edisi Revisi. Cetakan keenam. Jakarta : Bumi Aksara.

Bumi Aksara.

2012. Manajemen Sumber Daya Manusia. Jakarta : 
Kusriyanto, Bambang. 2005. Meningkatkan Produktivitas Karyawan. Jakarta : PT. Gramedia Pustaka Utama.

Mangkunegara, Anwar P. 2011. Manajemen Sumber Daya Manusia Perusahaan. Bandung: Remaja Rosdakarya.

Nitisemito, Alex S. 2000. Manajemen Personalia: Manajemen Sumber Daya Manusia, Ed.3. Jakarta: Ghalia Indonesia.

Prawirosentono, Suyadi. 2002. Manajemen Sumber Daya Manusia: Kebijakan Kinerja Karyawan. Yogyakarta : BPFE.

Rivai, Veithzal. 2013. Manajemen Sumber Daya Manusia Untuk Perusahaan Dari Teori ke Praktik. Jakarta : Raja Grafindo Persada.

Robbins SP, dan Judge. 2002. Perilaku Organisasi. Jakarta : Salemba Empat.

Robbins, Stephen, P. 2003. Prinsip-Prinsip Perilaku Organisasi. Jakarta: Erlangga.

Sastrohadiwiryo , B. Siswanto. 2013. Manajemen Tenaga Kerja Indonesia (Pendekatan Administratif dan Operasional). Jakarta : Bumi Aksara.

Saydam, Gouzali. 2006. Manajemen Sumber Daya Manusia Suatu Pendekatan Mikro. Jakarta : Djambatan.

2012. Manajemen Sumber Daya Manusia. Jakarta : Toko Gunung Agung.

Sedarmayanti. 2009. Sumber Daya manusia dan Produktivitas Kerja. Bandung : Mandar Maju.

Septianingrum, Ravela. 2011. Pengaruh Lingkungan dan Pengawasan Kerja terhadap Produktivitas Kerja Karyawan di PT. Yuro Mustika Purbalingga. Skripsi, Fakultas Ekonomi Universitas Negeri Semarang.

Siagian, P. Sondang. 2008. Manajemen Sumber Daya Manusia. Edisi pertama. Jakarta : Bumi Aksara.

Sihombing. 2006. Manajemen. Jakarta : Gramedia Pustaka.

Simamora, Henry. 2004. Manajemen Sumber Daya Manusia. Edisi Ke-3. Yogyakarta : STIE YKPN.

Sinamo, Jansen. 2005. Delapan Etos Kerja Profesional : Navigator Anda Menuju Sukses. Bogor : Grafika Mardi Yuana. 
Singarimbun, Masri dan Sofian Effendi. 2006. Metode Penelitian Survei. Jakarta : Pustaka LP3ES

Sinungan, Muchdarsyah. 2014. Produktivitas Apa dan Bagaimana. Bandung: Bumi Aksara.

Sofyandi, Herman. 2008. Manajemen Sumber Daya Manusia. Yogyakarta : Graha Ilmu.

Sopiah. 2008. Perilaku Organisasional. Edisi Satu. Yogyakarta : Andi.

Supriyanto, Agus. 2007. Pengaruh Motivasi Kerja dan Disiplin Kerja Terhadap Produktivitas Kerja Karyawan pada PT. Adatex di Boyolali. Skripsi, Fakultas Ekonomi Universitas Muhammadiyah Surakarta.

Sugiyono. 2012. Memahami Penelitian Kualitatif. Bandung : Alfabeta.

------------. 2013. Metode Penelitian Kuantitatif Kualitatif dan $R \&$ D. Bandung: Alfabeta.

Tasmara, Toto. 2002. Membangun Etos Kerja Islam. Jakarta : Gema Insani Pers

Tohardi, Ahmad. 2002. Pemahaman Praktis Manajemen Sumber Daya Manusia. Bandung : Mandar Maju.

Wahyudi. 2011. Manajemen konflik Dalam Organisasi. Bandung : CV Alfabeta. 